\title{
Analisis dan Peningkatan Kapasitas Apron di Bandara Halim Perdanakusuma
}

\author{
Immaculata Citra Di Januari ${ }^{1}$, Adita Utami ${ }^{1}$, Iswandaru Widyatmoko ${ }^{1,2}$ \\ ${ }^{1}$ Program Studi Teknik Sipil, Fakultas Perencanaan Infrastruktur, Universitas Pertamina \\ ${ }^{2}$ Department of Pavement Engineering, Centre of Excellent for Asset Consultancy, AECOM.
}

Email: $\underline{\text { citra0701@gmail.com. }}$ 2adita.utami@universitaspertamina.ac.id ${ }^{3}$ daru.widyatmoko@aecom.com

\begin{abstract}
This research presents evaluation and planning to increase the capacity of apron at Halim Perdanakusuma International Airport. The purpose of this study is to determine the number of aircraft that will use the apron in the planned year, and assess whether a new design for the apron will be required for the planned, which is 2030. This planning used 3 scenarios that differentiated based on the year of data used. The procedure was started by determining the future aircraft movement using simple linear regression. After that, the procedure continued by determining the values of Rmonth, Rday, and Rhour which then were multiplied by the result of regression to get the values of Nmonth, Nday, and Nhour respectively. The Nhour value was used as a basis or reference for designing additional capacity of the apron. The results of Nhour value for each scenario werw 57 movements for the first scenario, 44 movements for the second scenario, and 32 movements for the third scenario. For the maximum parking time duration of 45 minutes, the required additional parking will increase from 16 parking stand to 43 parking stands for the first scenario, 35 parking stands for the second scenario, and 24 parking stands for the third scenario.
\end{abstract}

Keywords: Apron, Parking Stand, Parking Time, Airport, Capacity

\begin{abstract}
Abstrak
Penelitian ini membahas tentang peningkatan kapasitas pada Apron di Bandar Udara Internasional Halim Perdanakusuma meninjau dari hasil evaluasi kapasitas apron yang ada saat ini. Penelitian ini bertujuan untuk mengetahui jumlah pesawat yang akan menggunakan apron pada tahun rencana yang kemudian akan ditentukan desain baru untuk apron agar dapat melayani pergerakan pesawat ditahun rencana yaitu tahun 2030. Perancangan ini dilakukan dengan menggunakan 3 skenario yang dibedakan berdasarkan tahun data yang digunakan. Proses dimulai dengan melakukan regresi linear sederhana untuk memperkirakan jumlah pergerakan pesawat dimasa mendatang. Lalu dilanjutkan dengan menentukan nilai Rmonth, Rday, dan Rhour yang kemudian dikalikan dengan nilai hasil regresi untuk mendapatkan nilai Nmonth, Nday, dan Nhour. Nilai Nhour pada tahun rencana dijadikan dasar atau acuan untuk melakukan desain penambahan kapasitas pada apron. Adapun hasil daripada Nhour ditahun rencana pada masing - masing skenario adalah 57 pergerakan untuk skenario pertama, 44 pergerakan untuk skenario kedua, dan 32 pergerakan untuk skenario ketiga. Dengan durasi parking time maksimal 45 menit makan dibutuhkan penambahan parking stand dari 16 parking stand menjadi 43 parking stand untuk skenario pertama, 35 parking stand untuk skenario kedua, dan 24 parking stand untuk skenario ketiga.
\end{abstract}

Kata kunci: Apron, Parking Stand, Parking Time, Bandara, Kapasitas

\section{Pendahuluan}

Tingginya minat masyarakat akan penggunaan transportasi udara menyebabkan Bandar Udara Internasional Soekarno Hatta mengalami kelebihan kapasitas [1]. Jumlah penumpang transportasi udara pada Bandar Udara Internasional Soekarno Hatta terus mengalami peningkatan setiap tahunnya. Kapasitas Bandara Soekarno Hatta hanya untuk melayani 43 juta penumpang pertahun. Namun pada kenyataannya ditahun 2014 bandara ini sudah harus melayani hingga lebih dari 57 juta penumpang pertahun. Untuk dapat melayani tingginya permintaan masyarakat akan penggunaan transportasi udara, 
di Ibu Kota DKI Jakarta sendiri saat ini sudah memiliki dua Bandar Udara yang beroprasi sebagai bandara komersil, yaitu Bandar Udara Internasional Soekarno Hatta dan Bandar Udara Internasional Halim Perdanakusuma. Bandara Halim Perdanakusuma sendiri resmi beroperasional sejak Januari 2014 dengan kapasitas mencapai 2 juta penumpang pertahun. Namun ditahun kedua bandara ini beroperasi bandara ini sudah mengalami kelebih kapasitas dan terus meningkat hingga ditahun 2018 sudah harus melayani lebih dari 7 juta penumpang pertahun [2]. Peningkatan ini tentu berdampak pada pada operasional sisi lain salah satunya apron pada fasilitas sisi udara. Apron merupakan tempat bagi pesawat untuk melakukan kegiatan ground handling setelah dan sebelum digunakan. Kegiatan ground handling yang dilakukan berupa pengisian bahan bakar, loading bagasi, penumpang, dan catering, pembersihan kabin pesawat, dan perbaikan singkat [3]. Terbatasnya kapasitas apron menyebabkan terjadinya waktu tunggu yang merupakan waktu yang dihasilkan bila ada dua atau lebih pesawat yang mengantri untuk menggunakan apron [4]. Lamanya penggunaan apron oleh sebuah pesawat biasanya terjadi karena beberapa faktor seperti sistem parkir yang digunakan, waktu pesawat melakukan putar balik, waktu perbaikan sebuah pesawat (waktu ini bisa berbeda pada tiap maskapai), dan waktu untuk kegiatan ground handling[5]. Aktivitas yang hendak dilakukan di apron harus dilakukan dengan waktu yang paling efisien, hal ini dikarenakan apron yang memiliki beberapa fungsi. Pihak pengelola harus melakukan pengaturan atau penjadwalan yang paling baik untuk mengoptimalkan penggunaan apron yang kapasitasnya terbatas. Seperti salah satunya adalah meningkatkan kualitas dari apron itu sendiri. Peningkatan kualitas yang bisa dilakukan seperti penambahan kapasitas ataupun pemaksimalan waktu penggunaan apron.

Peningkatan kapasitas apron biasanya dilakukan untuk dapat mengakomodasi pergerakan pesawat ditahun rencana atau tahun mendatang. Kegiatan peramalan dalam perencanaan suatu fasilitas umum biasanya akan membutuhkan waktu dan biaya yang besar karena metode yang rumit serta data yang dibutuhkan cukup banyak [6]. Menurut ICAO (2006), salah satu metode yang dapat digunakan untuk memprediksi pergerakan ditahun mendatang adalah metode time-series [7].

\section{Metode}

Studi analisis dan evaluasi terhadap peningkatan kapasitas apron dilakukan berdasarkan tahapan berikut ini:

\section{Peramalan Pertumbuhan Pergerakan Tahun Rencana dengan metode Regresi}

Perbandingan terhadap tipe regresi dalam metode time series dilakukan untuk menentukan hasil regresi yang terbaik dalam mengakomodasi pergerakan dalam tahun rencana [8]. Perbandingan dilakukan terhadap tipe regresi eksponensial, linear, logaritmik, dan polinomial. Adapun persamaan yang didapatkan dari setiap regresi terdapat pada Tabel 1.

Tabel 1. Persamaan Regresi

\begin{tabular}{ll}
\hline \multicolumn{1}{c}{ Tipe Regresi } & \multicolumn{1}{c}{ Persamaan } \\
\hline Eksponensial & $Y=a e^{b X}$ \\
Linear & $Y=a+b X$ \\
Logaritmik & $Y=a \ln (X)-b$ \\
Polinomial & $Y=a X^{2}+b X+c$
\end{tabular}

Pada hasil regresi menggunakan metode ini akan didapatkan nilai $\mathrm{R}^{2}$ atau koefisien determinasi dengan batas limit sama dengan satu dan nol, semakin hasilnya mendekati satu maka semakin dekat proyeksi dengan data sebenarnya [9] [10].

\section{Penentuan Jam Puncak}

Pada penentuan peak hour ditahun rencana, terlebih dahulu dibutuhkan nilai rasio berupa Peak Month Ratio (Rmonth), Peak Day Ratio (Rday), dan Peak Hour Ratio (Rhour)[11]. Kemudian nilai tersebut dikalikan dengan nilai regresi untuk mendapatkan jumlah pergerakan pada bulan sibuk (Nmonth), hari sibuk (Nday), dan jam sibuk (Nhour). Nhour nantinya akan digunakan sebagai basis 
data atau acuan merencanakan kapasitas apron baru. Penentuan nilai $\mathrm{R}$ dan $\mathrm{N}$ menggunakan persamaan pada Tabel 2.

Tabel 2. Persamaan Penentuan Jam Puncak

\begin{tabular}{ll}
\hline Parameter & \multicolumn{1}{c}{ Rumus } \\
\hline Rmonth & $\frac{\text { Nmonth }}{\text { Nyear }}$ \\
Rday & $\frac{\text { Nday }}{\text { Nmonth }}$ \\
Rhour & $\frac{\text { Nhour }}{\text { Nday }}$ \\
Nmonth & Nyear $\times$ Rmonth \\
Nday & Nmonth $\times$ Rday \\
Nhour & Nday $\times$ Rhour \\
\hline
\end{tabular}

Pada persamaan penentuan jam puncak, $\mathrm{R}$ merupakan nilai untuk rasio dan $\mathrm{N}$ merupakan nilai untuk jumlah pergerakannya, baik pergerakan bulan, hari, maupun jam.

\section{Pengecekan Kapasitas Apron}

Penentuan kapasitas apron dimulai dengan terlebih dahulu mengetahui kapasitas apron eksisting dan dilanjutkan dengan perhitungan rasio kapasitas apron [11] [12]. Penentuan apron eksisting dilakukan dengan tiga pendekatan menggunakan tiga parking time berbeda (30, 40, dan 45 menit). Pendekatan ini dimaksudkan untuk mengetahui bagaimana kapasitas apron eksisting berdasarkan parking time tersebut untuk selanjutnya salah satu parking time digunakan sebagai acuan desain. Perhitungan kapasitas apron dan rasionya dilakukan dengan persamaan (1) dan persamaan (2).

$$
\begin{aligned}
& \text { Kapasitas Apron }=\frac{\text { Jumlah Parking Stand }}{\text { Waktu di apron } / 60} \\
& \text { Rasio Kapasitas Apron Eksisting }=\frac{\text { Jumlah Pesawat yang dilayani }}{\text { Jumlah Parking Stand }}
\end{aligned}
$$

\section{Penentuan kapasitas apron baru}

Untuk menentukan parking time yang akan digunakan perlu diketahui kebutuhan parking stand untuk tahu rencana berdasarkan parking time yang berbeda. Selanjutkan diilustrasikan kebutuhan parking stand untuk mengetahui parking time yang akan digunakan. Pengilustrasian ini akan menyesuaikan kebutuhan parking stand dengan ketersedian lahan. Penentuan parking stand didapatkan dari hasil perhitungan menggunakan persamaan (3).

$$
\text { Kapasitas Apron }=\frac{\text { Jumlah Pesawat yang Dilayani }}{\text { Ratio Kapasitas Apron Eksisting }}
$$

\section{Hasil dan Pembahasan}

Pada studi ini, dilakukan tiga skenario yang dalam melakukan peramalan, hal ini bertujuan untuk mengetahui perbandingan hasil peramalan pada beberapa data yang berbeda. Perbedaan penggunaan data dipengaruhi oleh beberapa hal yaitu: Terjadinya kartal karena peningkatan tarif tiket pesawat dan beroperasinya Jalan Tol Trans Jawa pada tahun 2019 serta Pandemi Covid-19 pada tahun 2020 .

Skenario pertama digunakan data ditahun 2014 hingga tahun 2018 atau tahun sebelum adanya penurunan yang cukup signifikan pada data. Skenario kedua akan menggunakan keseluruh data termasuk data outlier, data yang digunakan adalah data di tahun 2014 hingga tahun 2020. Sedangkan skenario ketiga akan dilakukan menggunakan data tahun $2014-2020$. Hal yang membedakan skenario kedua dan ketiga adalah, data yang digunakan pada tahun 2020. Skenario ketiga akan melakukan sedikit rekayasa data untuk mengatasi data outlier. Data tahun 2020 di Bulan April hingga Desember 
merupakan data outlier. Data outlier sendiri merupakan data yang memiliki karakteristik unik yang berbeda jauh dari observasi - observasi lainnya dan muncul dalam bentuk nilai ekstrim baik untuk sebuah variabel tunggal atau kombinasi. Grafik penentuan data oulier dapat dilihat pada Gambar 1, sedangkan data pergerakan yang digunakan dapat dilihat pada Tabel 3.

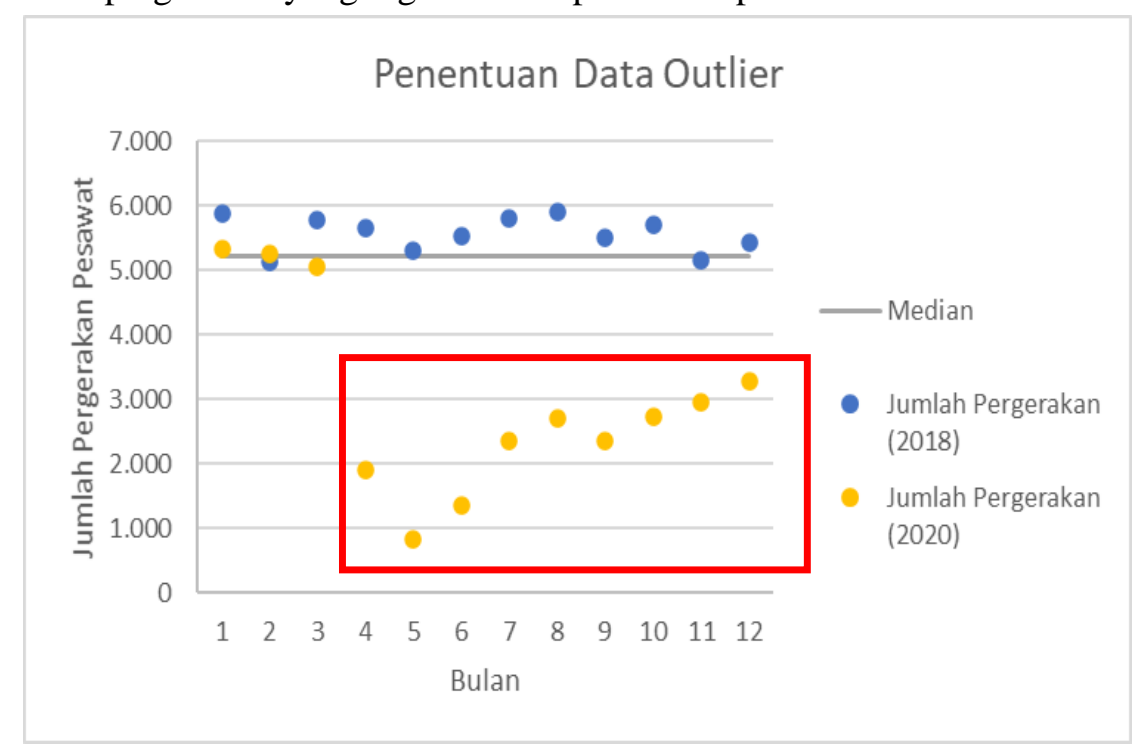

Gambar 1. Grafik Penentuan Data Outlier

Tabel 3. Jumlah Pergerakan Pesawat Pertahun

\begin{tabular}{cccc}
\hline \multirow{2}{*}{ Tahun } & \multicolumn{3}{c}{ Jumlah Pergerakan Pesawat Pertahun } \\
& Skenario Pertama & Skenario Kedua & Skenario Ketiga \\
\hline 2014 & 29.144 & 29.144 & 29.144 \\
2015 & 39.024 & 39.021 & 39.021 \\
\hline 2016 & 56.174 & 56.174 & 56.174 \\
2017 & 67.389 & 67.389 & 67.389 \\
2018 & 66.776 & 66.776 & 66.776 \\
2019 & - & 61.987 & 61.987 \\
2020 & - & 36.150 & 62.624 \\
\hline
\end{tabular}

Nilai rekayasa pada tahun 2020 didapatkan dengan cara mengkalikan nilai rata - rata pada Bulan Januari 2020 hingga Bulan Maret 2020 yang kemudian nilai rata - rata tersebut dikalikan dengan jumlah bulan dalam satu tahun. Nilai yang sudah dikali dengan jumlah bulan dalam satu tahun inilah yang digunakan sebagai nilai total pergerakan baik pada kedatangan, keberangkatan, dan juga total. Adapun detail pergerakan puncak pada bulan, hari, dan jam pada setiap skenario dapat dilihat pada Tabel 4.

Tabel 4. Jumlah Pergerakan Pesawat Per Parameter Waktu Per Skenario

\begin{tabular}{cccc}
\hline 'arameter Puncak & \multicolumn{2}{c}{ Skenario } & \\
& $\begin{array}{c}\text { Pertama } \\
\text { (Pergerakan) }\end{array}$ & $\begin{array}{c}\text { Kedua } \\
\text { (Pergerakan) }\end{array}$ & $\begin{array}{c}\text { Ketiga } \\
\text { (Pergerakan) }\end{array}$ \\
\hline Bulan & 5.907 & 5333 & 5.219 \\
Hari & 212 & 209 & 174 \\
Jam & 19 & 19 & 16 \\
\hline
\end{tabular}




\section{Peramalan Pergerakan Pesawat dengan Metode Regresi}

Tabel 5. Perbandingan Hasil Persamaan Regresi dan Nilai Koefisien Korelasi SKENARIO PERTAMA

\begin{tabular}{ccc} 
Tipe Regresi & Persamaan Regresi & R2 \\
\hline Eksponensial & $\mathrm{Y}=25.381 \mathrm{e}^{0,2204 \mathrm{X}}$ & 0,8543 \\
Linear & $\mathrm{Y}=10.363 \mathrm{X}+20.613$ & 0,9235 \\
Logaritmik & $\mathrm{Y}=26.082 \ln (\mathrm{X})+26.728$ & 0,9450 \\
Polinomial & $\mathrm{Y}=-1.922,9 \mathrm{X}^{2}+21.900 \mathrm{X}+7.152,2$ & 0,9680 \\
\hline
\end{tabular}

Berdasarkan hasil regresi pada Tabel 5, diketahui untuk hasil regresi dengan nilai $\mathrm{R}^{2}$ terbesar pada setiap skenario terdapat pada regresi polinomial dengan hasil nilai $\mathrm{R}^{2}$ sebesar 0,9680. Namun, regresi polinomial menghasilkan suatu hasil sebaran yang bernilai negatif sehingga jika digunakan hasil dari regresi polinomial maka akan ada penurunan jumlah penumpang yang mencapai nilai negatif ditahun 2030. Hasil penurunan ini juga tidak relevan dengan data statistik untuk jumlah penduduk dan Produk Domestik Regional Bruto (PDRB) pada provinsi DKI Jakarta. Menurut data dari Badan Pusat Statistik Provinsi DKI Jakarta, nilai untuk jumlah penduduk dan PDRB mengalami peningkatan setiap tahunnya. Adapun data tersebut dapat dilihat pada Tabel 6.

Tabel 6. Data Statistik DKI Jakarta

\begin{tabular}{|c|c|c|}
\hline Tahun & $\begin{array}{l}\text { Jumlah } \\
\text { Penduduk } \\
\text { (Ribu Jiwa) }\end{array}$ & $\begin{array}{c}\text { PDRB } \\
\text { (Juta Rupiah) }\end{array}$ \\
\hline 2015 & $10.179,0$ & 1.989.088.747,71 \\
\hline 2016 & $10.265,3$ & $2.159 .073 .617,96$ \\
\hline 2017 & $10.348,3$ & $2.365 .353 .854,95$ \\
\hline 2018 & $10.428,0$ & 2.592.606.571,93 \\
\hline 2019 & $10.504,1$ & $2.816 .760 .054,16$ \\
\hline 2020 & $10.576,4$ & $2.772 .381 .118,28$ \\
\hline
\end{tabular}

Dengan pertimbangan data statistik Provinsi DKI Jakarta dan hasil regresi yang didapatkan, maka ditentukan hasil penggunaan regresi yang cukup baik adalah tipe linear dan tipe logaritmik. Adapun hasil perbandingan antara hasil regresi linear dengan regresi logaritmik pada tahun 2030 adalah 196.782 pergerakan untuk regresi linear dan 100.627 pergerakan untuk tipe logaritmik. Selisih pada nilai $\mathrm{R}^{2}$ dikedua jenis regresi ini cukup kecil yaitu sebesar 0,0215 namun menghasilkan regresi pergerakan pesawat pada tahun 2030 dengan perbedaan yang cukup signifikan. Hal ini cukup mendasari pemilihan metode regresi linear dalam tahap analisis data. Hasil regresi linear yang lebih besar dibandingkan logaritmik membuat kapasitas yang nantinya akan dihasilkan dari regresi ini akan lebih banyak sehingga bisa mengakomodasi kemungkinan pergerakan yang lebih besar dari pada hasil pada regresi logaritmik. Adapun hasil regresi pada tahun 2030 untuk pergerakan pesawat terdapat pada Tabel 7.

Tabel 7. Hasil Regresi Linear Tahun 2030

\begin{tabular}{cc}
\hline Skenario & $\begin{array}{c}\text { Hasil } \\
\text { (Pergerakan) }\end{array}$ \\
\hline Pertama & 196.782 \\
Kedua & 86.953 \\
Ketiga & 127.609 \\
\hline
\end{tabular}




\section{Penentuan jam puncak}

Tabel 8. Hasil Nilai R dan N pada Setiap Skenario

\begin{tabular}{llll}
\hline \multicolumn{1}{c}{ Hasil } & \multicolumn{3}{c}{ Skenario } \\
& \multicolumn{1}{c}{ Pertama } & \multicolumn{1}{c}{ Kedua } & \multicolumn{1}{c}{ Ketiga } \\
\hline Rmonth & 0,090 & 0,150 & 0,080 \\
Rday & 0,036 & 0,039 & 0,030 \\
Rhour & 0,090 & 0,091 & 0,090 \\
Nmonth (2030) (pergerakan) & 17.711 & 13.043 & 10.634 \\
Nday (2030) (pergerakan) & 638 & 508 & 354 \\
Nhour (2030) (pergerakan) & 58 & 46 & 32 \\
\hline
\end{tabular}

\section{Pengecekan kapasitas apron eksisting}

Tabel 9. Kapasitas Apron Berdasarkan Parking Time

\begin{tabular}{cc} 
Parking Time & Kapasitas \\
\hline 30 menit & 32 \\
40 menit & 24 \\
45 menit & 21 \\
\hline
\end{tabular}

\section{Penentuan kapasitas apron baru}

Tabel 10. Kebutuhan Parking Stand

\begin{tabular}{lccc}
\hline & \multicolumn{3}{c}{ Jumlah Parking Stand } \\
\multicolumn{1}{c}{ Skenario } & $\begin{array}{c}\text { 30 menit } \\
\text { (a) }\end{array}$ & $\begin{array}{c}\text { 40 menit } \\
\text { (b) }\end{array}$ & $\begin{array}{c}\text { 45 menit } \\
\text { (c) }\end{array}$ \\
\hline Pertama & 28 & 38 & 43 \\
Kedua & 23 & 30 & 35 \\
Ketiga & 16 & 21 & 24
\end{tabular}

Berdasarkan peninjauan ketersedian lahan di wilayah Bandar Udara Internasional Halim Perdanakusuma maka dapat diketahui bahwa bandara ini dapat dilakukan pengembangan dengan parking time maksimum 45 menit. Untuk Kapasitas baru Skenario pertama sampai skenario ketiga dapat dilihat pada Gambar 2 - Gambar 4.

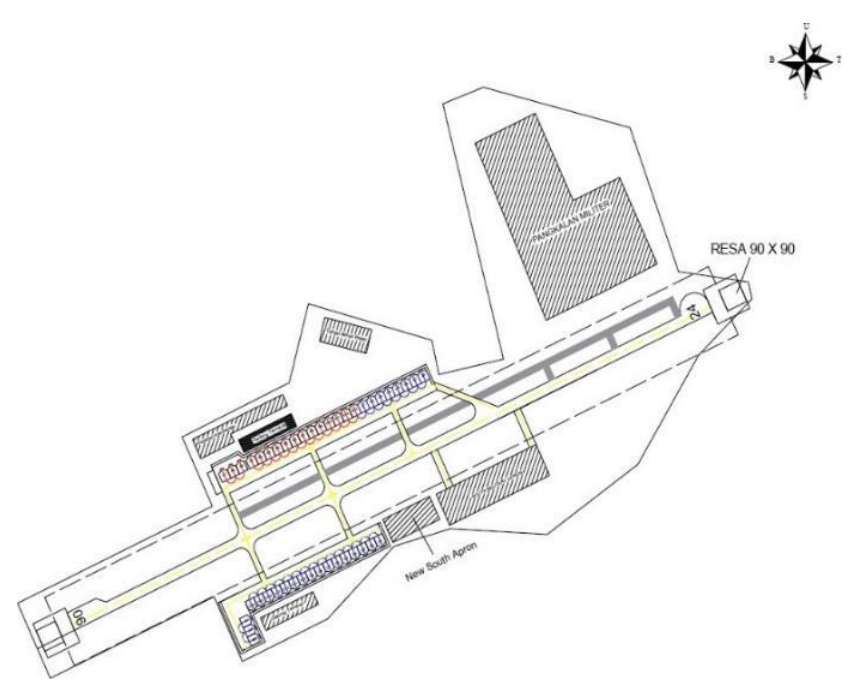




\section{Gambar 2. Kapasitas Baru Skenario Pertama}

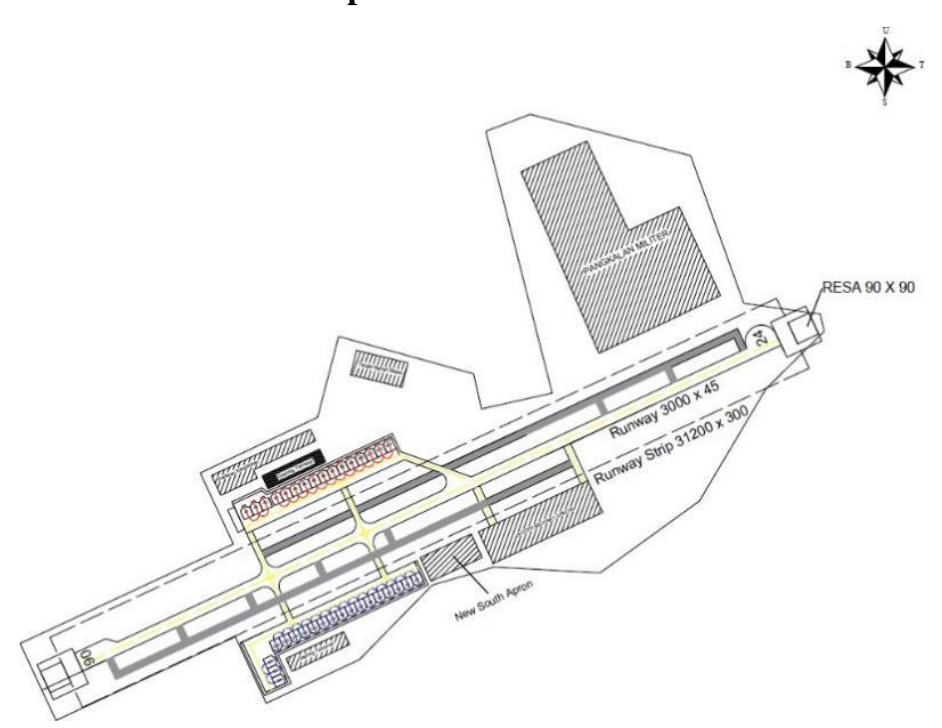

Gambar 3. Kapasitas Baru Skenario Kedua

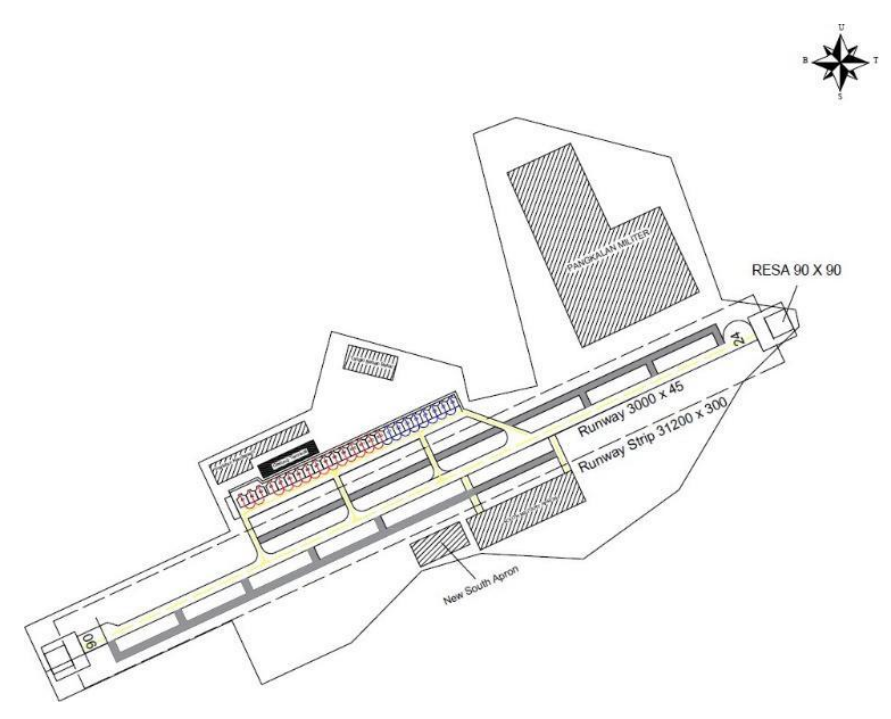

Gambar 4. Kapasitas Baru Skenario Ketiga

\section{Kesimpulan}

Dari hasil analisis yang dilakukan didapatkan bahwa jumlah pesawat yang menggunakan apron pada tahun 2018 dan 2019 mencapai 21 pergerakan pada jam puncak. Jumlah pesawat yang menggunakan apron dijam puncak pada tahun rencana diketahui dengan dilakukannya peramalan menggunakan regresi linear sederhana. Hasil pergerakan pesawat dijam puncak pada tahun rencana mencapai 58 pergerakan pada skenario pertama, 46 pergerakan pada skenario kedua, dan 32 pergerakan pada skenario ketiga. Selain itu, kondisi apron eksisting saat ini dihitung dengan tiga parking time, didapatkan hasil kapasitas apron eksisting masih dapat melayani pergerakan pesawat pada jam puncak dengan kapasitas maksimum 32 pesawat untuk parking time 30 menit, 24 pesawat untuk parking time 40 menit, dan 21 pesawat untuk parking time 45 menit. Untuk wilayah Bandara Halim Perdanakusuma masih dapat digunakan untuk pengembangan apron dengan parking time maksimum adalah 45 menit. Parking stand yang dibutuhkan untuk dapat melayani pergerakan pesawat dijam puncak pada tahun rencana mencapai 43 parking stand untuk skenario pertama, 35 parking stand untuk skenario kedua, dan 24 parking stand untuk skenario ketiga. 


\section{Referensi}

[1] D. Yuliana, "Strategi Pengembangan Pelayanan Publik di Bandar Udara Internasional Soekarno Hatta - Cengkareng," Wartha Ardhia J. Perhub. Udar., vol. 41, no. 4, pp. 181-200, 2015.

[2] A. H. Wibowo, R. D. Ramadhan, and B. Riyanto, "Analisis kapasitas bandara halim perdanakusuma sebagai bandara komersil," J. Karya Tek. Sipil, vol. 4, no. 4, pp. 172-188, 2015, [Online]. Available: file:///C:/Users/Basri/Downloads/9896-19105-1-SM.pdf.

[3] H. A. P. L. Hestuningrum and E. Ahyudanari, "Manajemen Kendaraan Ground Handling di Terminal 1 Bandara Internasional Juanda," War. Ardhia, vol. 44, no. 2, pp. 99-106, 2019, doi: 10.25104/wa.v44i2.333.99-106.

[4] A. Ratnakusuma, A. Hoyyi, and Sugito, "Analisis Sistem Antrian Pesawat Terbang Di Bandara Internasional Ahmad Yani Semarang," Gaussian, vol. 4, no. 4, pp. 725-733, 2015.

[5] H. Rahayu, E. Ahyudanari, and J. T. Sipil, "Evaluasi Kinerja Gate Assignment pada Terminal 1 Keberangkatan Domestik Bandar Udara Internasional Juanda Surabaya," vol. 5, no. 1, pp. 1-6, 2016.

[6] R. Horonjeff, F. X. McKelvey, W. J. Sproule, and S. B. Young, Planning and design of airports. McGraw-Hill Education, 2010.

[7] ICAO, "Manual on Air Traffic Forecasting," 2006.

[8] D. Setiawan, "Analisis Kapasitas Apron dan Ruang Tunggu Keberangkatan Penumpang Pesawat pada New Yogyakarta International Airport," Semesta Tek., vol. 22, no. 1, pp. 31-40, 2019, doi: $10.18196 /$ st.221234.

[9] A. Utami and H. Widyastuti, "Model Panjang Antrian Kendaraan pada Perlintasan Sebidang Tanpa Palang Pintu (Studi Kasus: Perlintasan Sebidang Jl. Gayung Kebonsari Surabaya)," J. Apl. Tek. Sipil, vol. 17, no. 1, p. 27, 2019, doi: 10.12962/j2579-891x.v17i1.4693.

[10] A. Utami and H. Widyastuti, "STUDY OF SOCIETY BEHAVIOUR TO EARLY WARNING IN THE RAILWAY LEVEL CROSSING WITHOUT BARRIER IN GAYUNG KEBONSARI , SURABAYA.” M.I.P.I, vol.14, no.1, pp. 39-46, 2020, doi:https://doi.org/10.29122/mipi.v14i1

[11] M. Nursalim, E. Ahyudanari, and I. Istiar, "Evaluasi Kebutuhan Luasan Apron Pada Rencana Pengembangan Bandar Udara Internasional Ahmad Yani Semarang," J. Tek. ITS, vol. 6, no. 1, 2017, doi: 10.12962/j23373539.v6i1.22504.

[12] A. A. V. Paendong, L. I. R. Lefrandt, and A. L. E. Rumayar, "Analisis Kapasitas dan Optimalisasi Apron Bandar Udara Internasional Sam Ratulangi Manado,” J. Sipil Statik, vol. 8, no. 2, p. 176, 2020. 